http://dx.doi.org/10.4314/gjl.v4i2.2

\title{
CONJOINT AND DISJOINT VERB ALTERNATIONS IN DAGBANI
}

\author{
Samuel Alhassan Issah
}

\begin{abstract}
The goal of this paper is to understand the nature and functions of aspectual suffixes of Dagbani, a language belonging to the South-Western languages of the Western Oti-Volta subgroup of the Gur group of languages. The paper considers the morphology of the verb and how it may be correlated with readily observable syntactic features of the language such as the presence or absence of certain arguments. The aspectual suffixes have different realisations which call for the presence or absence of certain structural arguments such as NP complements and adjuncts referred to as conjoint (CJ) and disjoint (DJ) verb forms respectively. I also propose three accounts in an attempt to account for the function(s) of the conjoint and disjoint alternations: the incorporated pronoun hypothesis, the medio-passive hypothesis, and the focus hypothesis, and conclude that the CJ/DJ forms are directly correlated with focus. It is concluded then that the CJ form correlates with focus on post-verbal materials, while the DJ focuses on the verb. The paper also discusses certain post-verbal particles whose distribution is affected by the aspectual markers. I give the paper a comparative flavour by drawing data from other languages of the Oti-Volta subgroup (excluding the Eastern languages) to buttress my claim based on empirical evidence that the phenomenon discussed is quite pervasive in this subgroup of Gur languages. The analysis is basically from a theory-neutral perspective. I conclude that the interaction between the aspectual suffixes and the sentence structure of Dagbani is (at least superficially) very similar to the so-called 'short/long' or 'conjunctive/disjunctive' verb which has been argued to be phenomenal in a number of Bantu languages.
\end{abstract}

Key Words: Dagbani, aspect, sentence structure, conjoint, disjoint, focus hypothesis, Gur. 


\section{Introduction}

This paper seeks to analyse and understand the nature and functions of suffixes and sentence structure in Dagbani (South Western Oti-Volta), a central Gur language spoken by the Dagbamba in Northern Ghana. The canonical word order of Dagbani is basically Subject, Verb, Object (SVO), also called Agent Verb Object. Dagbani has three major dialects which include: Tomosili, (the Western dialect) spoken in Tamale and its surroundings, Nayahali (the Eastern dialect), spoken in and around Yendi, and Nanuni, which is also spoken around Bimbilla and its surroundings. Noticeable dialectal differences are basically phonological and lexical without any known syntactic/structural differences. The data for the study is drawn from two different sources: data taken from students' written works, and examples generated by the author using native speaker intuitions. The use of data from written texts has been motivated by the fact that in general, it is better to get someone else's speech in linguistic analysis, since it is not influenced by the particular research agenda. Though a native speaker of the Tomosili dialect myself, the generalizations concerning the verb morphology and its interaction with the sentence structure could not be limited to a particular dialect of Dagbani, since interactions with speakers of the other two dialects show that similar patterns exist in Nayahali and Nanuni as well. ${ }^{1}$

Though there is a terminological split amongst linguists regarding the concept "aspect", in this paper it is used to refer to the 'view-point aspect'. This is because when 'aspect' is used as a cover term in Gur languages, it always concerns the 'narrow' form. Adger (2004: 50) argues that the "semantic difference between ongoing and completed action is one of aspect". Natural languages basically distinguish between 'ongoing' and 'completed' actions denoted by the verb via the concept of aspect. Typologically, in most natural languages a two-way aspectual distinction is made,

\footnotetext{
${ }^{1}$ I am grateful to the Editor-in-Chief of the Ghana Journal of Linguistics, Professor Mary Esther Kropp Dakubu and the anonymous reviewers of GJoL for their critical comments which have contributed to improving this paper. Every analytical error however remains mine.

The Kusaal data was collected while I was in Bawku for fieldwork with support from the Ghana Institute of Linguistics, Literacy and Bible Translation in March and June 2006. I am grateful to my consultants: Moses Atiigah, Rev Joshua Sofo, Rev. James Abariga, Alice Abanga, Aaron Abuosi and George A. Alalbila of the Kusaal Language and Development Project for their patience in assisting me with the data collection. I also express my profound gratitude to Dr. Paul Schaefer of the Ghana Institute of Linguistics, Literacy and Bible Translation, Safaliba Project, for checking this paper for language.
} 
between perfective and imperfective aspects. Traditionally, the imperfective aspect includes the habitual and progressive forms of the verb. The distinction between the perfective and imperfective forms of the verb is very important as they help users of a particular language to codify different situations associated with the action of the verb. I therefore define aspect as that grammatical property of verbs which indicates whether the action denoted by the verb is viewed as perfected or ongoing.

The correlation between verbal forms (morphology) and presence or absence of complements and adjuncts within the sentence structure has been noted to be a phenomenal property of Bantu languages: by Buell (2005, 2006), Nurse (2006), Creissels (1996), Givon (1975), van der Wal (2013), Sharman (1956), Voeltz (2004) among others. Different Bantu scholars have used different terminologies to refer to this verbal paradigm. For instance Buell and Riedel (2008) use conjoint and disjoint, Creissels (1996) uses the terms conjunctive and disjunctive, while in the Nguni languages, the terms long and short are pervasive. The conjoint form cannot appear clause-finally, while the disjoint form canonically does appear in clause-final position. For instance a Bantu syntactician, Van der Wal (2009: 217) submits that:

a very salient and easily detectable difference between the verb forms is their sentence-final distribution: the CJ forms need to be followed by some other element, while the DJ form can occur sentence finally, although it does not need to.

While research into Dagbani continues to attract attention in recent times, there are some areas that remain largely understudied. For instance, there is an interesting morphological feature of the verb that could broaden our understanding about Gur languages and natural languages in general. Specifically interesting about the morphology of the verb is the interaction between the verb morphology and sentence structure. A look at recent publications reveals that the 'disjoint/conjoint' theme is currently a much debated issue, also for non-Bantu languages. I will establish that the verb morphological feature of aspectual suffixation has some correlation with the syntactic consideration as to whether the verb occurs clause-finally or clausemedially, indicating that there is an interaction between verbal morphology and sentence form. ${ }^{2}$

\footnotetext{
${ }^{2}$ Abbreviations used in this paper are: 1st, 2nd, 3rd for first, second, and third person respectively, ADJUN=adjunct, $\quad \mathrm{AFF}=$ affirmative, $\mathrm{ATR}=$ advanced tongue root, $\mathrm{CJ}=$ conjunction, $\mathrm{COMPL}=$ completive aspect, $\mathrm{DEF}=$ definite, $\mathrm{DJ}=$ disjoint, $\mathrm{FOC}=$ focus, $\mathrm{IMPERF}=$ imperfective, $\mathrm{NEG}=$ negative, $\mathrm{NP}=$ noun phrase, $\mathrm{PERF}=$ perfective, $\mathrm{PL}=$ plural, $\mathrm{PROG}=$ progressive, $\mathrm{POSS}=$ Possessive, $\mathrm{PST}=$ past, $\mathrm{PVP}=$ post verb particle, $\mathrm{QUAN}=\mathrm{Quantifier}, \mathrm{TRM}=$ time reference marker, $\mathrm{SG}=$ singular.
} 
Specifically, this work demonstrates that: (i) the marking of aspect is a morphological phenomenon in Dagbani, (ii) the perfective and imperfective aspect come in different morphological forms, (iii) there is a close relationship between aspectual suffixes and the presence or absence of certain arguments such as NP objects and adjuncts within the sentence structure, (iv) the distribution of the postverb particles is affected by the purely surface consideration of whether the verb is final in the clause or not, (vi) the conjoint/disjoint verb alternation can be accounted for using the focus hypothesis, and (vi) the interaction seen between the post-verb particles and the aspect system of Dagbani appears to be a typological phenomenon which can be observed in several other Gur languages in the Oti-Volta subfamily. Dakubu (1989) and Saanchi (2003) identify a similar verbal paradigm in Dagaare, a genetically related language, and use the terminologies 'perfective A', 'perfective B' and 'imperfective $A$ ' and 'imperfective $B$ ' to describe the phenomenon.

The discussion in this paper is structured as follows: section 2 discusses the verb morphology of Dagbani, highlighting the syntactic requirements of the conjoint/disjoint alternations, while section 3 discusses negation and the verbal paradigm. Section 4 investigates the correlation between ex-situ focus and the conjoint/disjoint forms; section 5 considers relativisation and the morphology of the verb form, while section 6 discusses possible accounts/uses of the CJ/DJ verb forms with a discussion on the interaction between the verbal paradigm and post-verb particles, drawing data from genetically closer languages and aimed at making some generalizations with regard to Oti-Volta typology. Section 7 concludes the paper with a summary of findings.

\section{The Morphology of the Dagbani Verb}

In Dagbani, there is no known work that discusses the aspectual suffixes of Dagbani and their interaction with the sentence structure. Though Olawsky (1999) rightly identifies the perfective and imperfective forms of the verb, he does not go into details such as the different morphological shapes and different syntactic requirements of the two forms. A brief overview of the morphology of the verb is crucial in understanding the phenomenon that is discussed in this paper. Morphologically, the Dagbani main verb may be identified by the forms shown in Table 1.

In Table 1, the forms in column $E$ are verbal nouns derived via the use of the derivational suffix identified as -bú. This morpheme can be identified as the class marker -bú. Almost all Gur languages use class suffixes for marking verbal nouns (since the noun class suffixes very often display additional derivative functions); in O$\mathrm{V}$ languages verbal nouns are derived preferably by means of -bú. 
Table 1: The forms of the Dagbani verb

\begin{tabular}{|l|l|l|l|l|l|}
\hline A & B & C & D & E & Gloss \\
\hline kú PERF & DJ PERF & CJ IMPERF & $\begin{array}{l}\text { DJ IMPERF } \\
\text { Nominal }\end{array}$ \\
\hline dàm & kú-yà & kú-rì & kú-rá & kú-bù & kill \\
\hline nyú & dàm-yà & dàm-dí & dàm-dá & dàm-bú & shake \\
\hline páy & nyú-yà & nyú-rì & nyú-rá & nyú-bú & drink \\
\hline worí & páy-yà & páy-dí & páy-dá & páy-bú & borrow \\
\hline kohí & worí-yà & worí-tì & worí-tá & worí-bú & split \\
\hline dì & kohí-yà & kohí-rì & kəhí-rá & kohí-bú & sell \\
\hline tú & dì-yà & dì-rì & dì-rá & dì-bú & eat \\
\hline
\end{tabular}

Nicole (1999:4-5) makes a typological remark on the verb morphology of Gur languages and asserts that:

...the basic distinction is between an incompletive and a completive (or some cases neutral) forms, these forms often being distinguished by different suffixes, but also notably by tonal differences or vowel alternations...[v]erbs are generally verbo-nominal, that is they can be used both as verbs (on the addition of the appropriate aspect suffixes) and as nouns (on the addition of a class suffix)....very often, the form that is given as the 'infinitive' is really a nominal form, that is, a verb form, followed by noun class marker.

Nicole's arguments above on the verb morphology of Gur languages propose a two-way division, where the division may be indicated either by a suffix, and/or by tone. Accordingly, Nicole's description matches Dagbani very well since Dagbani marks the two-way distinction for the perfective and imperfective verb form by suffixes, as illustrated in Table 1. The proposal of a two-way contrast in the verb morphology is based on the observation that what other scholars have called the 'neutral' stem is identical to the conjoint perfective, both segmentally and suprasegmentally.

Naden (1988) gives a brief overview of the genetic classification of the Gur languages spoken in Ghana. His discussion does not exclude discussion on the verb. Naden (1988: 37) asserts that verbs in most Gur languages have 'two basic forms, perfective or neutral and imperfective'. He contends that in terms of morphology, there is basically a suffix that is attached to the neutral form of the verb to derive the 
imperfective. I use the terminologies 'imperfective' and 'perfective' to refer to what has been termed as 'incompletive' and 'completive' respectively by some other scholars (cf. Osam 2003).

\subsection{Illustrating the Conjoint/Disjoint Phenomenon in Dagbani.}

This section illustrates the phenomenon of conjoint and disjoint verb forms using empirical evidence. Table 2 shows sentential illustrations of verbal alternations.

Table 2: Sentential illustrations of Dagbani verbal alternations

\begin{tabular}{|c|c|c|}
\hline & CJ & DJ \\
\hline IMPERF & $\begin{array}{l}\text { Be kú-rì } \mathbf{X} \\
\text { 3PL kill.IMPERF X } \\
\text { 'They kill, they are killing X.' }\end{array}$ & $\begin{array}{l}\text { BE kú-rá } \\
\text { 3PL kill.IMPERF } \\
\text { 'They kill/are killing.' }\end{array}$ \\
\hline$\overline{\text { PERF }}$ & $\begin{array}{l}\text { Chentiwuni chìm- } \emptyset \mathbf{X} \\
\text { NAME fry.PERF X } \\
\text { 'Chentiwuni has fried X.' }\end{array}$ & $\begin{array}{l}\text { Chentiwuni chìm-yá } \\
\text { NAME chim.PERF } \\
\text { 'Chentiwuni has fried.' }\end{array}$ \\
\hline
\end{tabular}

The morphological alternation of the imperfective aspect is further illustrated in the sentences in (4) and (5).

4. a. Bì-hí máá dì-rá DJ

child-PL DEF eat.IMPERF

'The children eat/are eating'.

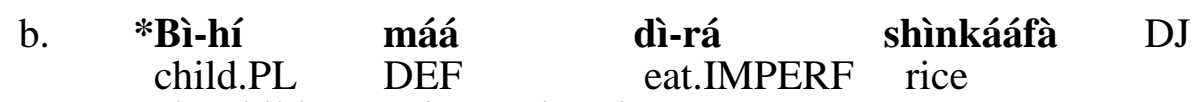

'The children eat/are eating rice.'

c. Bì-hí gbí-rì vó-yà

child.PL dig.IMPERF hole.PL

'Children dig/are digging holes'.

(Salifu 2012: 7)

d. *Bì-hí gbí-rì.

child.PL dig.IMPERF

CJ

'Children dig/are digging.'

5. a. $\quad B \varepsilon$ dàm-dí tì-hí gbá

3PL shake.IMPERF tree.PL too

'They shake/are shaking trees too.' 


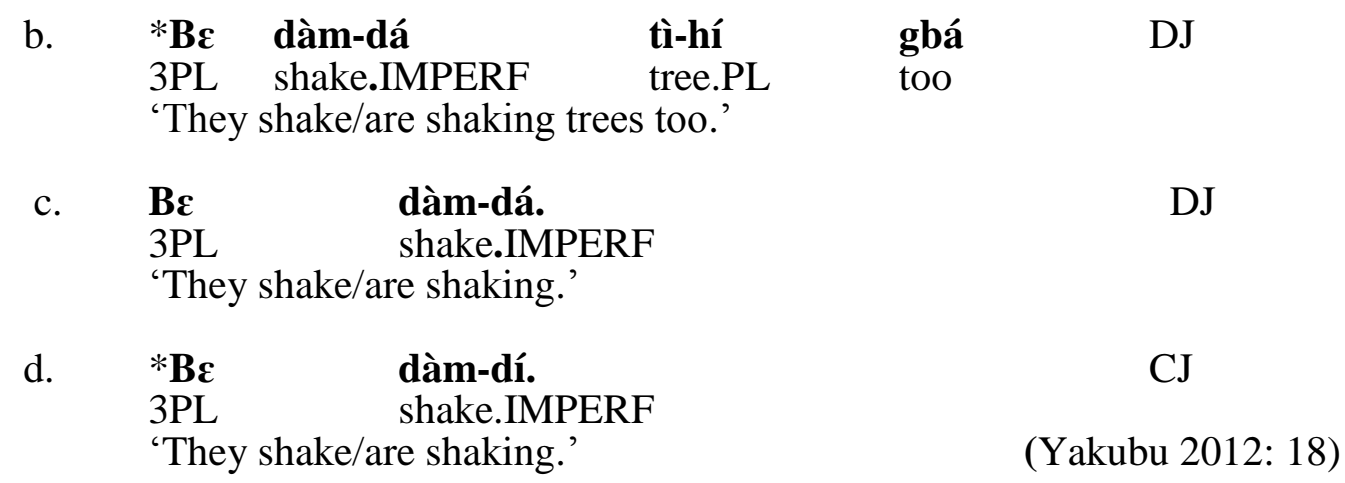

The evaluation of incompleteness or ungrammaticality of sentences (4d) and (5d) is because the aspectual suffix -ri is used and no linguistic material follows the verb. This suffix never occurs clause-finally, thus (4d) and (5d) appear to be incomplete and are ungrammatical. In contrast, the ungrammaticality of sentence (4b) and (5b) is because -ra is assigned a NP complement, shinkaafa 'rice' and tihi gba 'trees too'. The CJ/DJ verbal alternation in the imperfective aspect does not only affect the distribution of NP objects, but also adjunct phrases, such as adverbials (of manner, time and place etc) as illustrated in (6).

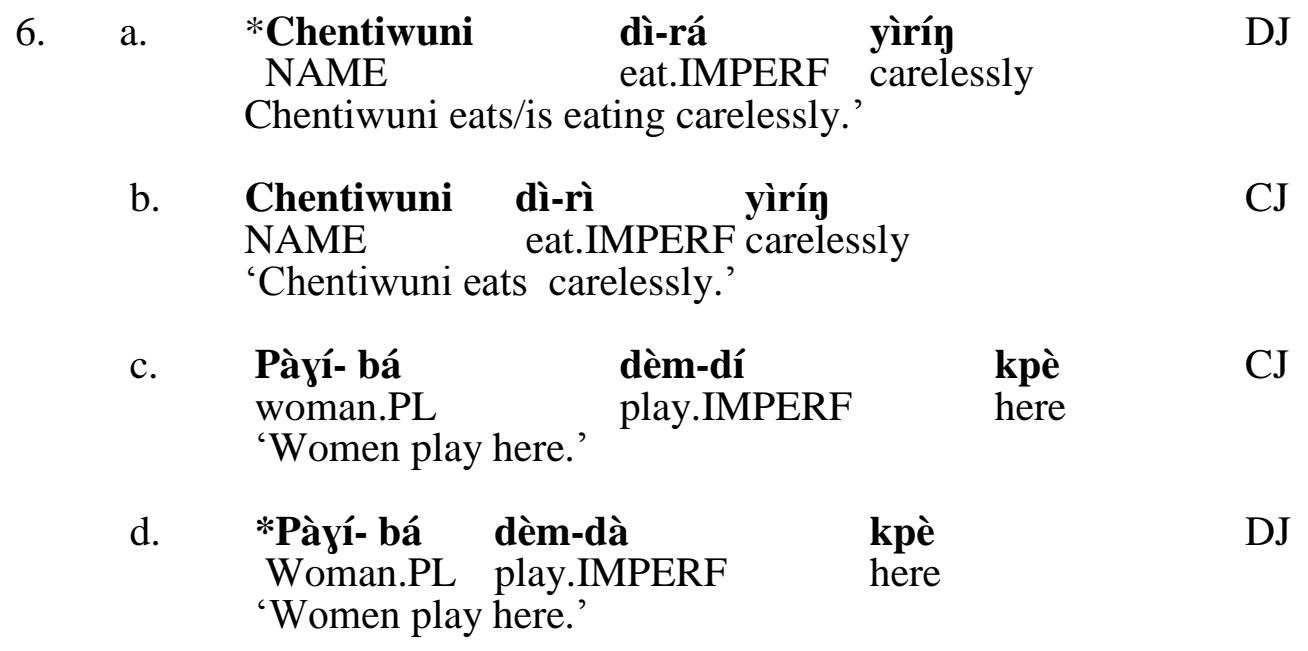

The ungrammaticality of (6a) arises from the fact that the 'disjoint' form of the imperfective aspect occurs with an adjunct phrase, in this case the adverb of manner yirin 'carelessly'. In sentence (6d) too, the ungrammaticality arises from the fact that the 'disjoint' form of the verb co-occurs with an adjunct of place kpe 'here'. I earlier 
argued based on empirical evidence that the 'disjoint' form canonically occurs in sentence final position, indicating that, syntactically, the disjoint aspectual suffix neither takes an NP object nor an adjunct.

The verbal alternation between the DJ and CJ forms is not only realizable in the imperfective aspect, but also in the perfective form of the verb. There are two different morphological forms of the perfective aspect, each of which comes with different syntactic requirements. The CJ perfective obligatorily requires an NP object or adjunct in its syntactic configuration; while the DJ perfective invariably marked with -ya does not occur with NP objects (whether full NP objects or pronoun objects). It can however, occur with adjuncts. This paradigm is shown in (7) and (8).
a. Gòlí máá
kpí-yà
moon DEF
die.PERF

DJ

'The month has ended.'

(Salifu 2012:7)

b.

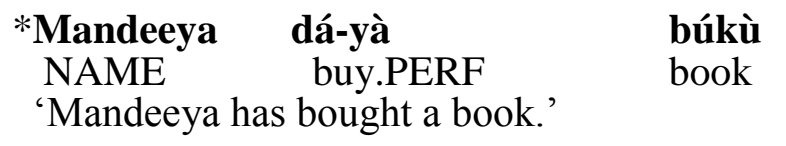

$\begin{array}{lclll}\text { Bì-hí } & \text { máá } & \text { sà }^{3} & \text { kú-yà } & \text { pàm } \\ \text { child.PL } & \text { DEF } & \text { TRM } & \text { kill.PERF } & \text { a lot }\end{array}$

'The children killed a lot yesterday.'

d.

*Mandeeya bú-yà $\stackrel{\text { ò }}{ }$
NAME beat.PERF
'Mandeeya beat him/her.'

e. *Mandeeya duhí-yà loori

DJ

NAME drive.PERF lorry

'Mandeeya has driven a lorry.'

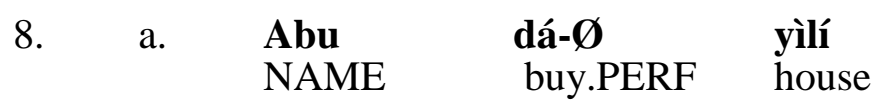

'Abu has bought a house.'

CJ

Salifu (2012:8)

\footnotetext{
${ }^{3}$ There are preverbal particles in Dagbani that mark the time reference of events: sa is one such particle which indicates that the action denoted by the verb is either a day away in the past or in the future. When it is to indicate that an action is a day away (in the future) it must occur obligatorily with the future particle ni.
} 


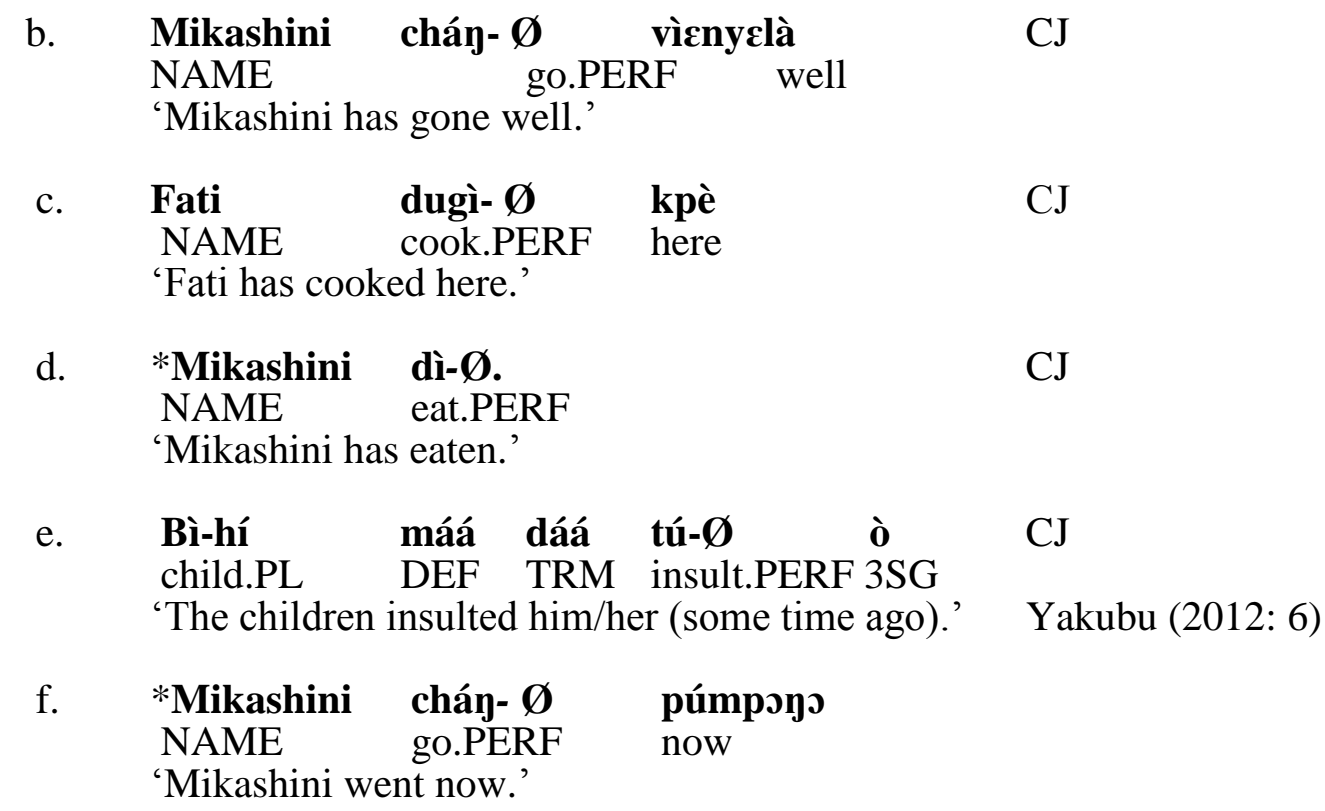

We observe in (7b) and (7d) that the DJ perfective cannot occur with NP objects (whether full NPs or pronominal NPs). The DJ perfective form is, however, compatible with adjuncts as in (7c). We also notice that the conjoint perfective form of the verb occurs with NP complements (8a). It does not only occur with full NPs as in (8a) but also pronominal objects as in (8e). It can also occur with manner adverbs as in (8b). Though the manner adverbial vienyela 'well' does not affect the grammaticality of the sentence in (8b), the grammaticality of sentence (8f) is affected by the time adverbial pumpons meaning 'now'. My conclusion is that the DJ perfective form does not occur with all kinds of adjuncts.

With a critical look at the verbal paradigm so far discussed, a reader immediately notes that there seems to be something striking about these aspect markers. We notice for instance that the imperfective disjoint has the morphemes -r$\mathbf{a} / \mathbf{d}-\mathbf{a} / \mathbf{t}-\mathbf{a}$ whilst the imperfective conjoint has the morphemes $-\mathbf{r}-\mathbf{i} / \mathbf{d}-\mathbf{i} / \mathbf{t}-\mathbf{i}$. With the perfective disjoint too, we could have -y-a. Comparing across forms, it seems reasonable for one to hypothesize that the $-\mathbf{r} / \mathbf{d}$ is probably the imperfective marker whilst the -a is the marker of disjoint form and the -i could be analyzed as a marker of conjoint property. This claim of possible separate morpheme segmentation is shown in a more picturesque manner in (9) and (10). 


\section{9. $\quad \mathbf{r} / \mathbf{d} / \mathbf{t}-\mathbf{i} \quad \mathbf{r} / \mathbf{d} / \mathbf{t}-\mathbf{a}$ \\ IMPERF -CJ IMPERF -DJ}

10. PERFECTIVE?

The morpheme separation analysis would seem unattractive given the fact that it works out for only the imperfective verbal alternation, but not the perfective. For instance, a segmentation of -ya into $\mathbf{y}-\mathbf{a}$ would rather be misleading, since all verbal stems end in a vowel so that $/ y /$ is not the perfective marker, but should better be interpreted as a glide between the final vowel and the morpheme /a/ which indeed can be identified as the morpheme that marks this special syntactic position. Therefore, we will rather deal with distinct aspectual markers rather than a separate CJ/DJ morpheme.

Saanchi (2003) also discusses the verb morphology of a genetically related language, Dagaare, and concludes that the perfective and imperfective aspect have two different forms with corresponding different syntactic requirements. He uses the terminologies 'perfective $A$ ' and 'perfective B', and 'imperfective $A$ ' and 'imperfective B' to describe the different morphological realizations. Saanchi (2003: 102) argues that the 'perfective A' is the same as the bare form of the verb, while the 'perfective B' suffix 'is a front mid vowel /e/ or $/ \varepsilon /$ depending on the ATR value of the root vowels'. Saanchi (2003) further indicates that in terms of syntactic requirement, the 'perfective $A$ ' is obligatorily followed by the post-verb particle la and an obligatory NP object or adjunct. He further points out that when the NP object is a pronoun the 'pronoun comes between the verb and the post verbal particle'. It will be demonstrated later in this work that similar conclusions are valid for the Dagbani post-verb la and other genetically related Gur languages. The 'perfective B' according to Saanchi (2003) is also followed by a NP object or an adjunct. It is also argued by Saanchi (2003) that the post-verb la may also follow the 'perfective B'.

The imperfective aspect also occurs in two morphological forms with different syntactic prescriptions. The 'imperfective A' according to Saanchi (2003) is 'followed obligatorily by the post verb particle la (9a) and an optional object (9b)'. He further demonstrates that when the verb is used intransitively, the clitic $-\boldsymbol{\eta}$ may be suffixed to the imperfective A as in (9c). The data is taken from Saanchi (2003:104).

$\begin{array}{lll}\text { 9. a. } & \text { a } \quad \text { bie di-re } & \text { la } \\ \text { DEF child eat-IMPERF AFF } & \text { 'The child is eating.' }\end{array}$


b. a bie di-re la a sIIma DEF child ear-IMPERF AFF DEF meal 'The child is eating the meal.'

c. a bie di-re-n

DEF child eat-IMPERF-AFF

'The child is eating.'

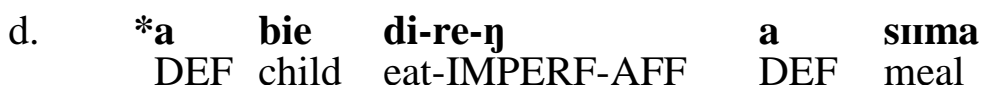

The 'imperfective B' according to Saanchi (2003:105) requires an obligatory object (3a) or adjunct (3b). It however, does not occur with pronouns object (9c). The 'imperfective B' does not also occur with post verb la or the clitic $-\mathbf{y}$ as shown in the ungrammaticality of (9d).

10.

DEF child weed-IMPERF DEF place

'The child is weeding the place'.

b. a bie di-ree sun

DEF child eat.IMPERF well

'The child is eating well'

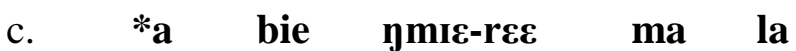

DEF child beat.IMPERF 1SG AFF.

'The child is beating me.'

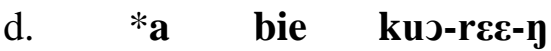

DEF child weed-IMPERF-AFF

'The child is weeding.'

These morphological alternations for the different aspect forms and their correlation with the sentence pattern of Dagbani shall be the focus of this paper.

\section{Negation and the Verbal Paradigm}

Negation in simple propositional logic is an operator that reverses the truth value of a proposition. Since negation is a fundamental grammatical feature of verb category, it is important to investigate the correlation between this verbal paradigm and negation. This is to establish how this verbal alternation manifests itself in 
negative polarity sentences. Dagbani marks negation using preverbal particles ku and bi for future and non-future negation respectively. The interaction between negation and the verbal alternation is exemplified in the sentences in (11) through (14).

The ungrammaticality of sentences (14a) and (14c) indicates that the disjoint perfective form of the verb does not occur in negative sentences, leading to the conclusion that the negation morpheme bi is not compatible with -ya. Possibly, Manessy (1963) is right in assuming that -ya has a strong perfective connotation. This assumption is in accordance with observations from other languages, where a perfective notion is not compatible with negation. It has been argued that something which is negated is to be seen as neutral with regard to the aspectual perspective. However, this morpheme (which seems to be an old Gur inheritance according to Manessy) has undergone different developments in the languages in question and where it has developed into a focus marker; the notion of perfectivity has been weakened.

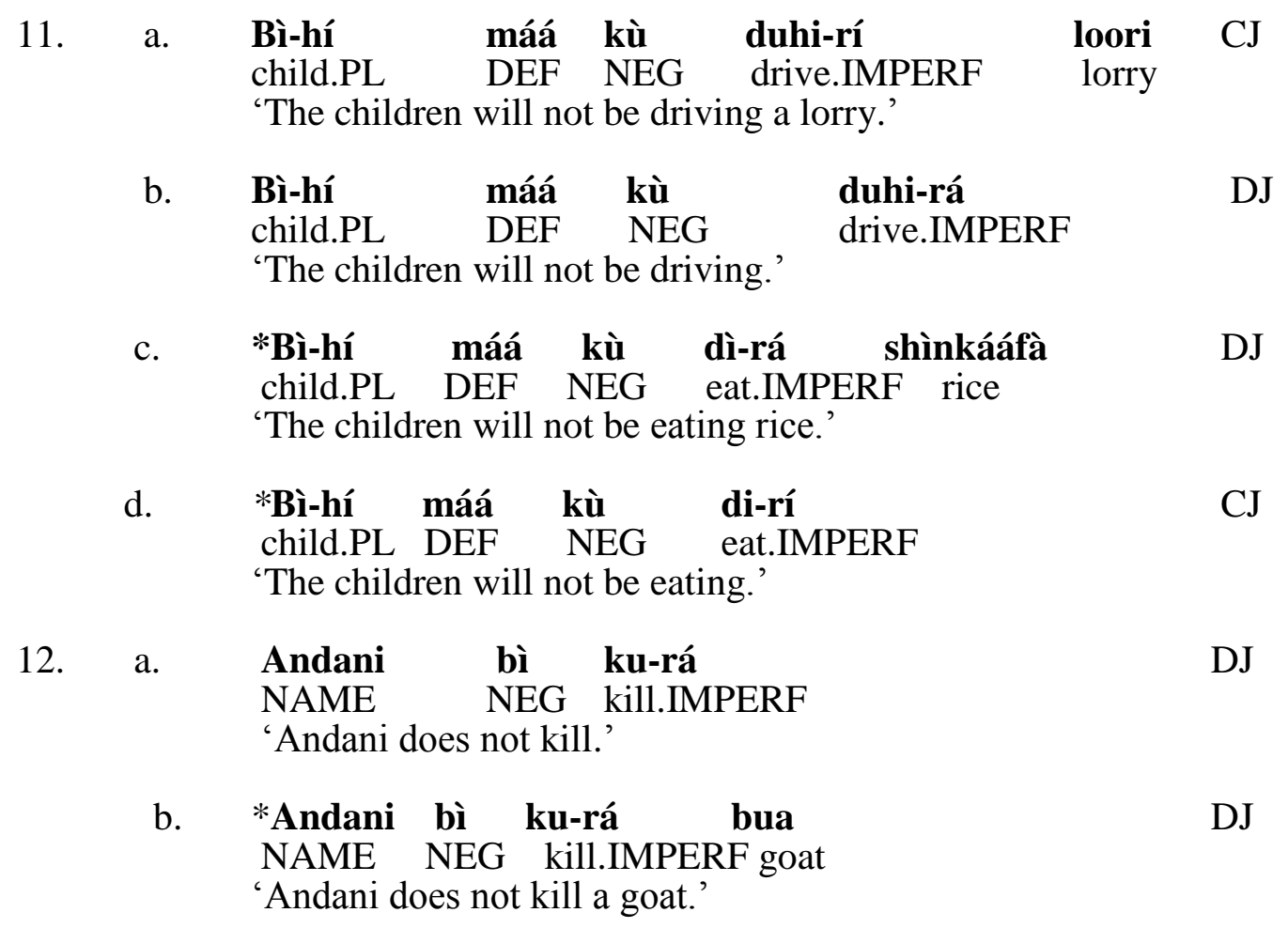


c. A bì vihí-rí $\quad$ yel-á

1SG NEG check.IMPERF matter.PL

'You don't investigate issues.'

CJ

Yakubu (2012:16)

d. *A bì vìí-rí.

CJ

2SG NEG check.IMPERF

'You don't investigate.'

$\begin{array}{lllll}\text { e. } & \text { M } & \text { bì } & \text { dìhí-rì } & \text { ò. } \\ & \text { 1SG } & \text { NEG } & \text { feed.IMPERF } & \text { 3SG }\end{array}$

'I do not feed him/her.'

CJ

Yakubu (2012:16)

f. $* \mathbf{M}$ bì dìhí-rì.

1SG NEG feed.IMPERF

'I do not feed.'

13. a. Abu bì dì-Ø shìnkááfà

NAME NEG eat.PERF rice

'Abu has not eaten rice'.

b. Abu bì dì-Ø.

CJ

NAME NEG eat.PERF

'Abu has not eaten'

$\begin{array}{llllll}\text { c. } & \text { Bì-á } & \text { bì } & \text { chàn-Ø } & \text { pùmpoł’ } & \text { CJ } \\ \text { child.SG } & \text { NEG } & \text { go.PERF } & \text { now } & \end{array}$

'A child has not gone now'

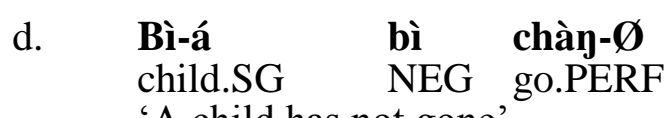

'A child has not gone'

14. a. *Bì-á máá bì chày-yà

child.SG DEF NEG go.PERF

CJ

'The child has not gone.'

$\begin{array}{llll}\text { b. Bì-á } & \text { máá } & \text { bì } & \text { chày-Ø } \\ \text { child.SG } & \text { DEF } & \text { NEG } & \text { go.PERF }\end{array}$

'The child has not gone.'

c. *Bì-á máá bì gbìhí-yà pùmpojo DJ child.SG DEF NEG sleep.PERF now

'The child has not fallen asleep now.' 
There is something worth noting about the manifestation of the conjoint forms in polarity sentences. It was earlier noted that the conjoint form does not appear clause finally, as it obligatorily requires some linguistic material to follow it. The grammaticality of (13b) and (13d) where the conjoint form occurs clause finally, however, indicates that this claim is not valid for negative polarity sentences. This then means that in negative polarity sentences, the conjoint perfective can appear in clause final positions. Detailed research is needed to understand this change of the syntactic requirement of the conjoint perfective form when it occurs with negation. The conclusion however, is that the morphological alternation is neutralized here in the CJ perfective form.

\section{Ex-situ Focus Marking and the Verbal Paradigm}

This section investigates the correlation between the DJ/CJ verb alternation and ex-situ focusing strategies. Ex-situ focus is marked within the left periphery of the clause using focus markers $\mathbf{k a}$, and $\mathbf{n}$ for non-subject and subject constituents respectively (Hudu 2006, 2012; Issah 2008, 2012; Olawsky 1999). The data in (15) and (16) illustate how focus marking is coded in the imperfective form of the verb and its correlation with the verbal alternation.

15. a. $\quad \mathbf{B} \boldsymbol{\varepsilon}$ tù-rí mà $\quad \mathrm{CJ}$

3PL insult.IMPERF me

'They are insulting me.'

b. Màní ká be tù-rá

1SG(EMPH) FOC 3PL insult.IMPERF

'It is me (that) they are insulting.'

c. *Màní ká be tù-rí

1SG(EMPH) FOC 3PL insult.IMPERF

CJ

'It is me (that) they are insulting.'

d. Bánì $\mathrm{n}$ tu-ri ma $\quad$ m

3PL FOC insult.IMPERF me

'They are insulting me.'

e. *Bánì $\mathbf{n}$ tù-rá mà $\quad$ DJ

3PL FOC insult.IMPERF me

'It's they who are insulting me.' 


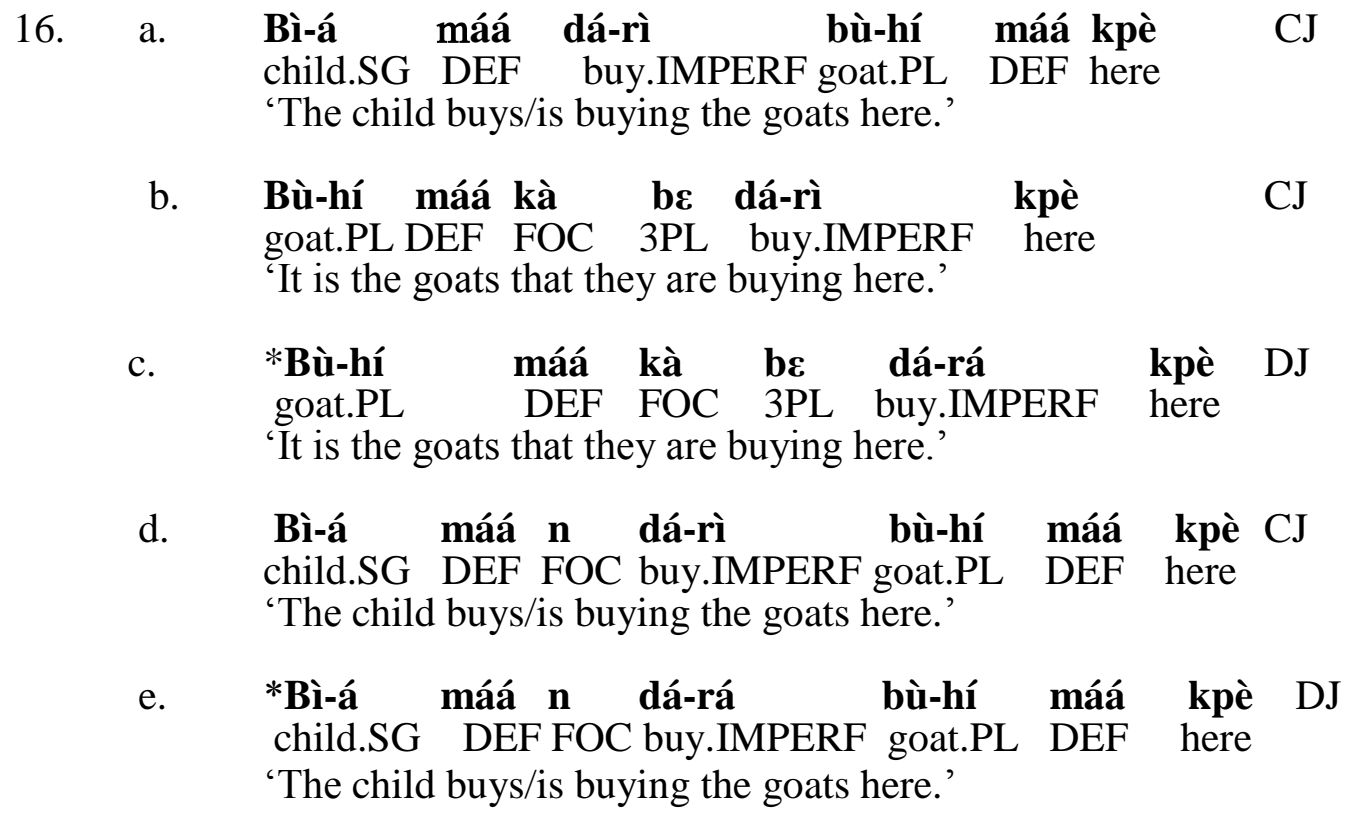

In (15b) when the object of the sentence ma 'me' is moved from the canonical position and brought to clause initial position, the verb form also changes from the 'conjoint' form turi 'insulting' to the 'disjoint' form tura 'insulting'. This change in the form of the verb in (15b) is necessitated by the fact that the verb is now in the clause final position after the movement of the object. The ungrammaticality of the sentence in (15c) demonstrates the claim that even in focus constructions, the CJ verb form cannot occur clause finally, at least in the simple sentence. It is therefore seen that in (16b), where buhi 'goats' is moved to clause initial for purposes of coding focus, it is the CJ aspectual form dari 'buying' that is used. A descriptive account of this is that the verb still has an element kpe 'here' after it and so does not appear in the clause final position. In (16c), the sentence is ungrammatical because the DJ form of the imperfective is used when the verb is not in the clause final position. The author therefore contends that in focus constructions, the verbal alternations of disjoint and conjoint forms are active just as in canonical sentences.

Having taken a look at the interaction between the verbal alternation and focus constructions in imperfective aspectual forms, it is necessary to take a look at the nature of focus constructions in the perfective aspectual forms. This, it is hoped, will allow a more acceptable generalization on the manifestation of the discussed verbal alternation. In the data that follow, I discuss focus constructions in the perfective form of the verb. It should be recalled that I have indicated that Dagbani marks the 
perfective aspect in two ways: via the use of the aspectual suffix -ya and the use of null morpheme $\boldsymbol{\varnothing} \boldsymbol{\emptyset}$. The realization of focus in the perfective aspectual paradigm is illustrated in the sentencs under (17) and (18)

17
a. Kayaba
kú-yà
NAME kill.PERF
'Kayaba has killed.'

DJ

b. *Kayaba n kú-yà

DJ

NAME FOC kill.PERF

'It is Kayaba who has killed.'
c. Kayaba n kú- $\emptyset$
NAME FOC kill.PERF

CJ

'It is Kayaba who has killed.'

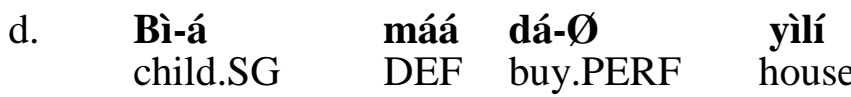

'The child has bought a house.'

$\begin{array}{llllll}\text { e. } & \text { Yilí } & \text { kà } & \text { bì-á } & \text { máá } & \text { dá-Ø } \\ & \text { house } & \text { FOC } & \text { child.SG } & \text { DEF } & \text { buy.PERF }\end{array}$

'It is a house that the child has bought.'
f. *Yilí
kà bì-á máá dá-yà
DEF buy.PERF
house FOC child.SG DEF
'It is a house that the child has bought.'

CJ

18. a. Bì-á máá sá chay-yà

child.SG DEF TRM go.PERF

'The child went yesterday.' Yakubu (2012:22)

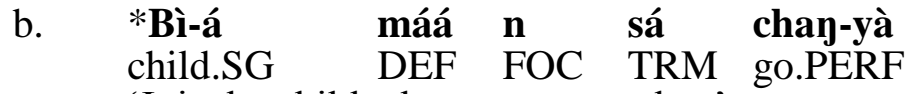
'It is the child who went yesterday.'

DJ
c. Bì-á máá $\quad$ n sá chay - $\varnothing$
child.SG DEF FOC TRM go.PERF
'It is the child who went yesterday'
d. Bì-á máá duhi- rì loori
child.SG DEF drive.IMPERF lorry
'The child drives/is driving a car'

DJ 

e. $\quad$ *Loori
lorry
ka bì-á
FOC child.SG
máá duhi- rì
DEF
drive.IMPERF
'It is a car that the child is driving/drives'
f. Loori
lorry
ka bì-á
FOC child.SG
máá duhi- rá
DEF drive.IMPERF
'It is a car that the child drives.'

It is clear from the data in (17) and (18) above that the focus marker $\mathbf{n} / \mathbf{k a}$ and the disjoint aspectual marker -ya cannot co-occur. Though the perfective CJ form of the verb does not occur clause-finally in the canonical sentence, in subject focus constructions this requirement is neutralised, and the $\mathrm{CJ}$ verb form occurs clause finally. It is striking, however, that the imperfective CJ, even in focus constructions, does not occur clause-finally. Even when it happens that the DJ form of the verb occurs with an adjunct (as discussed earlier), the paradigm described in (17) and (18) does not change. This is illustrated with data in (19).

19.
Bì-á
child.SG
máá sá lú-yà
DEF TRM fall.PERF
sohálá
DJ
'The child fell yesterday.'
b. *Bì-á máá $\mathbf{n} \quad$ sá lú-yà sohálá DJ child.SG DEF FOC TRM fall.PERF yesterday 'It is the child who fell yesterday.'

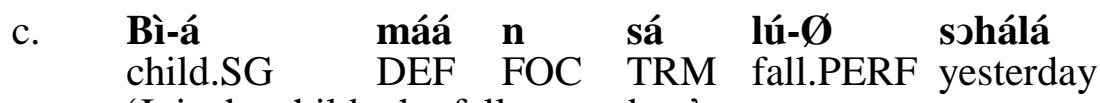
'It is the child who fell yesterday.'
$\begin{array}{lllll}\text { d. } \quad \text { *Sohálá kà bì-á } & \text { máá } & \text { sá } & \text { lú-yà } \\ \text { yesterday FOC } & \text { child.SG } & \text { DEF } & \text { TRM } & \text { fall.PERF }\end{array}$
'It was yesterday that the child fell.'

It is observed from this description that there is a co-occurrence restriction between the focus markers and the suffix -ya. This conclusion suggests that the /a/ forms do not convey aspect only, but are aspect forms modified by an additional function morpheme.

Having seen that the focus markers ka and $\mathbf{n}$ are incompatible with the perfective aspectual marker -ya in simple sentences, there is the need to investigate the phenomenon in subordinate clauses. The fact that the verb in the matrix clause in 
(20c) is suffixed with -ya is what is responsible for its ungrammaticality indicating that -ya and focus are mutually exclusive.

20. a. Abu tchí-yà ní Jemima dì-Ø
NAME think.PERF that Jemima eat.PERF food máná
'Abu thought that Jemima has eaten the food.'
b. *Abu n tchí-yà ní Jemima dì-Ø bìndírígù máá NAME FOC think.PERF that Jemima eat.PERF food DEF 'It was Abu who thought that Jemima has eaten the food.'
c. Bìndírígù máá ká Abu tchí-Ø ní Jemima dì-yà food DEF FOC NAME think.PERF that Jemima eat.PERF 'It is the food that Abu thought that Jemima has eaten.'
d. *bìndírígù máá ká Abu tchí-yà ní Jemima dì-yà. food DEF FOC Abu think.PERF that Jemima eat.PERF 'It is the food that Abu thought that Jemima has eaten.'

21. a. Abu tchí-yà ní bí-hì máá chàn-Ø dáà. NAME think.PERF that child.PL DEF go.PERF market 'Abu thought that the children have gone to the market.'

b. Bí-hì máá ká Abu tehí-Ø ní be chàn- Ø dáà children DEF FOC Abu think.PERF that 2PL go.PERF market 'It is the children that Abu thought have gone to the market.'

c. *Bí-hì máá ká Abu tehí-yà ní be chàn-Ø dáà. child.PL DEF FOC NAME think.PERF that 2PL go.PERF market. 'It is the children that Abu thought have gone to the market.'

It is also possible to focus the subject of an embedded clause, as in (21b) where the subject of the embedded clause, bihi maa, 'the children', has been focused. An interesting issue that is worthy of mention is the ungrammaticality of sentences (20d) and (21c). A plausible explanation to the ungrammaticality of these sentences may be that there is some relation between focus movement and verbal morphology in subordinate clauses. It is then observed, based on (20c) and (21b) that the verb that immediately precedes the subordinate clause of a focus constituent cannot be morphologically marked with the disjoint completive or perfective aspectual marker -ya as that yields ungrammatical forms. There is thus a prohibition of the presence of -ya on the intermediate verb in Dagbani, as seen from data. It is observed based on 
(20d) and (21c) that in successive cyclic movement, the verb in the matrix clause is invariably not marked with the perfective aspectual suffix -ya. When it is marked with the morpheme, the resulting structure is ungrammatical. Why -ya changes to conjoint form $-\varnothing$ in the matrix clause might therefore, be linked to prohibition on cooccurrence between focus and the -ya suffix.

\section{Relativisation and the Verbal Paradigm}

This section investigates the interaction between relativisation and CJ/DJ alternations. In relative clauses, the indefinite quantifiers so/sheba for singular and plural animate/count nouns, respectively and sheli/shena for singular and plural noncount nouns respectively, occur in their normal function as modifiers (indefinite quantifiers) of the antecedent, and the relative pronouns yùn and dìn, for living and non-living things respectively, occur within the relative clause to point back to the noun being modified. The relative pronouns also differ depending on whether the relativised element is singular or plural: yùn for singular and bàn for plural. Furthermore, the indefinite quantifiers also have the singular/plural and animacy dichotomy. When the indefinite quantifiers modify a noun in Dagbani, the noun loses part of it, usually the final syllable. For details on the indefinite quantifiers in Dagbani, see Issah (2013a).

I establish that the perfective DJ verb form does not occur in relativised clauses, be they relativised subjects as in $(22 \mathrm{~b}, 22 \mathrm{~d})$ or relativised objects as in (22f). Also, the imperfective DJ verb form does not also occur in relativised clauses, be they relativised subjects as in $(23 \mathrm{~b}, 23 \mathrm{~d})$ or relativised objects as in (23f). I conclude then that the DJ verb forms do not occur in relative clauses and that the CJ form cannot also occur clause finally even in relative clauses.

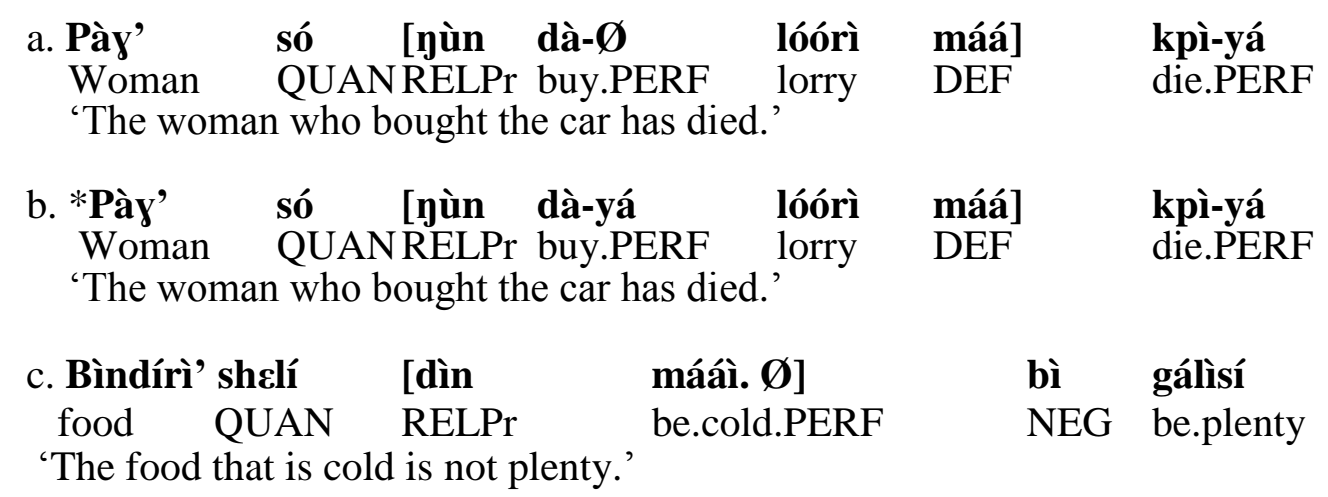


$\begin{array}{llllll}\text { d. *Bindiri' } & \text { sheli } & \text { [dìn } & \text { máá-yá] } & \text { bì } & \text { gálìsí } \\ \text { food } & \text { QUAN } & \text { RELPr } & \text { be.cold.PERF NEG } & \text { be.plenty }\end{array}$

The food that is cold is not plenty.'

e. Adam nyà-Ø bí' sheba [[bàn chàn-Ø dáà] máá NAME see.PERF child QUANRELPr go.PERF market DEF

'Adam has seen the children who went to the market.'

f. *Adam nyà bí' sheba [bàn chàn-yá dáà] máá NAME see.PERF child QUANRELPr go.PERF market DEF

'Adam has seen the children who went to the market.'

23.
a. Bu'
sheba [bàn
gúú-rì run.IMPERF
máá] bì
bàrá
goat.SG QUANRELPr
'The goats that are running are not fat.'
DEF NEG be.big

$\begin{array}{lllrll}\text { b. }{ }^{*} \text { Bú } & \text { sheba [bàn } & \text { gúú-rà } & \text { máá] } & \text { bì } & \text { bàrá } \\ \text { goat } & \text { QUANRELPr } & \text { run.IMPERF } & \text { DEF } & \text { NEG } & \text { be.big }\end{array}$ The goats that are running are not fat.'

c. Pày' sò [nùn chìm-dí nìmdí máá] màlí lìyírì woman QUANRELPr fry.IMPERF meat DEF has money

'The woman who fries the meat has money (is rich).'

\section{d. *Pày' sò [nùn chìm-dá nìmdí máá] màlí lìyírì} woman QUANRELPr fry.IMPERF meat DEF has money

'The woman who fries the meat has money (is rich).'

e. Nóómbì-h' sheba [bàn yìyí-rì $\quad$ zaa] màlí ànfáánì bird.PL QUANRELPr fly.IMPERF QUAN have benefits

'All flying birds have benefits (are beneficial)'.

\section{f. * Nóómbì-h' sheba [bàn yìyí-rà $\quad$ zaa] màlí ànfáánì bird.PL QUAN RELPr fly.IMPERF QUAN have benefits 'All flying birds have benefits (are beneficial)'}

The distinction between CJ/DJ verb forms therefore represents a packaging in different morphology of verbs, distributional properties (syntactic requirements) and information structure. The canonical properties of the CJ/DJ distinction is therefore summarised in (24): 
24. a. the use of different verbal suffixes (morphology) of the verb

b. different distributional properties within the clause

c. codes different information structural notion (focus)

d. difference in interaction with post verbal particles.

\section{Plausible Accounts of the Verbal Paradigm}

This section attempts to give possible accounts for the CJ/DJ alternation within the Dagbani verbal paradigm. I develop three plausible explanations for this morphological alternation: the incorporated pronoun hypothesis, the medio-passive morpheme hypothesis and then the focus hypothesis. Of the three hypotheses, I contend that the focus hypothesis seems to be the most adequate in addressing accounting for the verbal paradigm in the language.

\subsection{The Incorporated Pronoun Hypothesis.}

The incorporated pronoun hypothesis is stated in (25).

25. A verb appearing in the DJ form has an incorporated pronoun, while a verb appearing in the $\mathrm{CJ}$ form has no incorporated pronoun.

With this proposal, we maintain that the perfective DJ morpheme -ya and the imperfective CJ markers -ra or its variant -da and -ta are analyzable as incorporated pronouns. Accordingly, a verb that occurs in the disjoint form has an incorporated pronoun thereby prohibiting its co-occurrence with NP objects and sometimes adjunct phrases, whilst the conjoint form of the verb lacks an incorporated pronoun. Within this hypothesis, it implies that there are different ways in which objects are structurally realized in Dagbani; either they appear in their canonical placement as sisters to the head of a verb phrase, or they are incorporated, or adjoined at the sentence level, in which case they are morphologically attached to the verb. However, we soon see that the correlation between CJ/DJ alternations and the presence or absence of incorporated pronoun is imperfect, suggesting that the proposed incorporated pronoun hypothesis does not address the problem on the function or this verbal alternation. The weakness of this proposal is revealed in the fact that the forms of the verbs that are said to have incorporated pronouns do occur in medio-passives as in the sentences under (26).

26. a. $\quad \begin{aligned} & \text { Púú } \\ & \text { farm }\end{aligned} \quad$ máá $\quad \begin{gathered}\text { kó-yà } \\ \text { till.PERF }\end{gathered}$

DJ

'The farm is tilled.' 
b. Dàm máá bí-yà

DJ pito DEF cook.PERF 'The pito is cooked.'

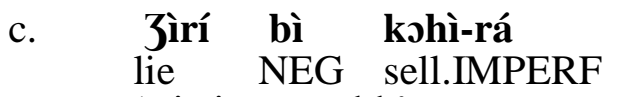

DJ

'Lie is not sold.'

Salifu (2012:18)

This observation is then taken to greatly weaken the proposal for an analysis in which the DJ aspectual suffixes $-\mathbf{y a}$ and $-\mathbf{r a} / \mathbf{d a} / \mathbf{t a}$ are analyzable as incorporated pronouns. This calls for another proposal which I call the medio-passive morpheme analysis.

\subsection{The Medio-passive Morpheme Hypothesis}

27. A verb that is used in the disjoint form has a medio-passive morpheme, -ya and -ra while a verb used in the conjoint form has no medio-passive morpheme.

This observation is in accordance with the general structural feature of many Gur languages in that with dynamic verbs the canonical structure SVO may change to $\mathrm{SV}$, but then the semantic role of S changes from agent to patient. However, different constraints are observed from language to language concerning the semantics of verbs as well of nouns in S position. For details see for instance, Reineke \& Miehe (2005).

However, there is evidence to indicate that this hypothesis, just like the incorporated pronoun hypothesis, does not address the problem of the function of this morphological alternation. A problematic fact for this hypothesis is the selectional restriction on NP subjects before a structure can be assigned medio-passive reading. Accordingly, only inanimate nominals (subjects) can assign the disjoint forms of the verb a medio-passive reading. When the NPs used are animate ones, the resulting sentences would still have active readings and not passive readings as in (28).

28
a. Mbayba
kó-yà
DJ
'Mbayba has tilled.'
b. Mbajba
Mbangba
dì-yà
eat.PERF
DJ
'Mbayba has eaten.'

Thus, the selective nature of the NP requirement in injecting medio-passivity into a sentence undermines the medio-passive morpheme analysis proposed to account for 
the alternation. The morphological expression of medio-passivization on the verb is therefore also found only to occur with some lapses.

\subsection{The Focus Hypothesis}

This proposal argues that the CJ/DJ verb alternation is associated with focus. I contend therefore, that the CJ verb form marks focus on whatever follows the verb, while the DJ verb form encodes focus on the verb. One would not be far from right to argue then that the formal requirement that something follows the CJ verb form is because the information structure requirement that it focuses some post verbal material. This explains why the CJ form cannot occur at the end of a sentence (at least in the main clause), while the DJ form of the verb focuses the verb and so occurs clause-finally. By the tenets of this proposal, Dagbani has two types of in-situ focus strategies: namely syntactic focus strategy coded by use of post verbal particles mi and la, (Olawsky 1999, Issah 2013b, Hudu 2012), and morphological focus, which is marked using the CJ and DJ verb forms. I therefore, pursue an analysis according to which CJ focuses post verbal elements, while the DJ form correlate with narrow verb focus, as demonstrated in (29).

29. a. Yí chìm-dá?

2PL fry.IMPERF

'Do you fry?'
b. ì̀n, tí chìm-dá
yes 1PL fry.IMPERF
'Yes, we fry.'

c. ì̀n, tí chìm-dí nyùlí

yes 1PL fry.IMPERF yam

'Yes, we fry yams.'

d. Yí chìm-yá?

2PL fry.PERF

'Have you fried?'

e. ì̀n, tí chìm-yá

yes 1PL fry.PERF

'Yes, we have fried.'

In (29), we demonstrate the morphological coding of in situ focus in Dagbani. In (29b) for instance, the focus is on the verb chim, 'fry' marked with the 
imperfective CJ morpheme -da, while in (29c), the focus is marked on nyuli 'yam' and so the CJ morpheme -di is used. The same observation is made of (29e) where -ya marks focus on the verb. Thus, whether the verb or post-verb material is the focal element calls for specific verb suffixes.

In the literature, scholars have argued that there is a correlation between verb form and the marking of predicate focus. Schwarz (2008) makes draws similar conclusions for Buli and labels the strategy as morphological means of marking predicate focus, and Sharman (1956) also draws similar conclusions in Bantu.

An observation that further strengthens my proposal that CJ focuses post verbal NP objects, complements and adjuncts while the DJ focuses the verb itself is based on the distribution of post verbal elements which are associated with syntactic focus in the study of Dagbani grammar. I demonstrate that the distribution of these post verb particles is affected by interaction with the aspect system and the purely surface consideration of whether the verb is final in the clause or not. This paradigm is demonstrated in (30).

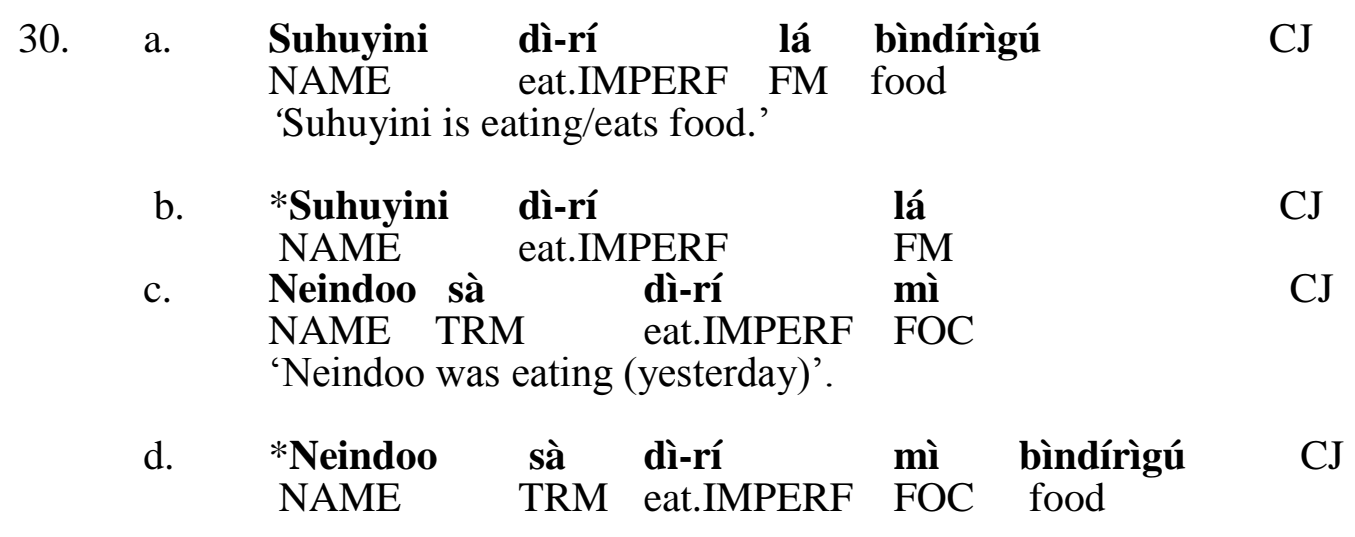

If it has so far been established that -ra and its variants occur clause finally while -ri and its variants occur when something must follow the verb, (at least in the simple sentence), then it stands to reason that la must be incompatible with -ra since the two have conflicting syntactic requirement. The incompatibility between the post verb la and the disjoint imperfective aspectual marker -ra explains the ungrammaticality of sentence (30a). The post verbal mi is also mutually exclusive with -ra and its variants. At least descriptively, one can suggest that the syntatic incompatibility between -ra and $\mathbf{m i}$ arises from the fact that the two have same syntactic features, they both occur clause finally (at least) in simple sentencess and for 
that matter, selecting one of them will suffice. This is evident in the ungrammatical sentence in $(30 \mathrm{~b})$.

30.
a.
*Suhuyini
NAME
dì-rá eat.IMPERF
lá bìndírìgú
DJ 'Suhuyini is eating/eats food.'
b.

$\begin{array}{lll}\text { *Neindoo } & \text { sà } \quad \text { dì-rá } & \text { mì } \\ \text { NAME } & \text { TRM eat.IMPERF } & \text { FOC } \\ \text { 'Neindoo was eating (yesterday).' } & \end{array}$

I therefore conclude that the occurrence of the post verb la and mi within a sentence is dependent on the aspectual marker that occurs on a verb. It must be pointed out however, that pronouns differ in their syntactic relations with the postverb particle la within the sentence structure of Dagbani. Pronouns, unlike full DPs, precede the post verb la instead of following it. This explains the ungrammaticality of sentences (31b) and (31d) where we have the pronouns ba 'them' and ma 'me' following la instead of preceding it as in sentences (31a) and (31c).

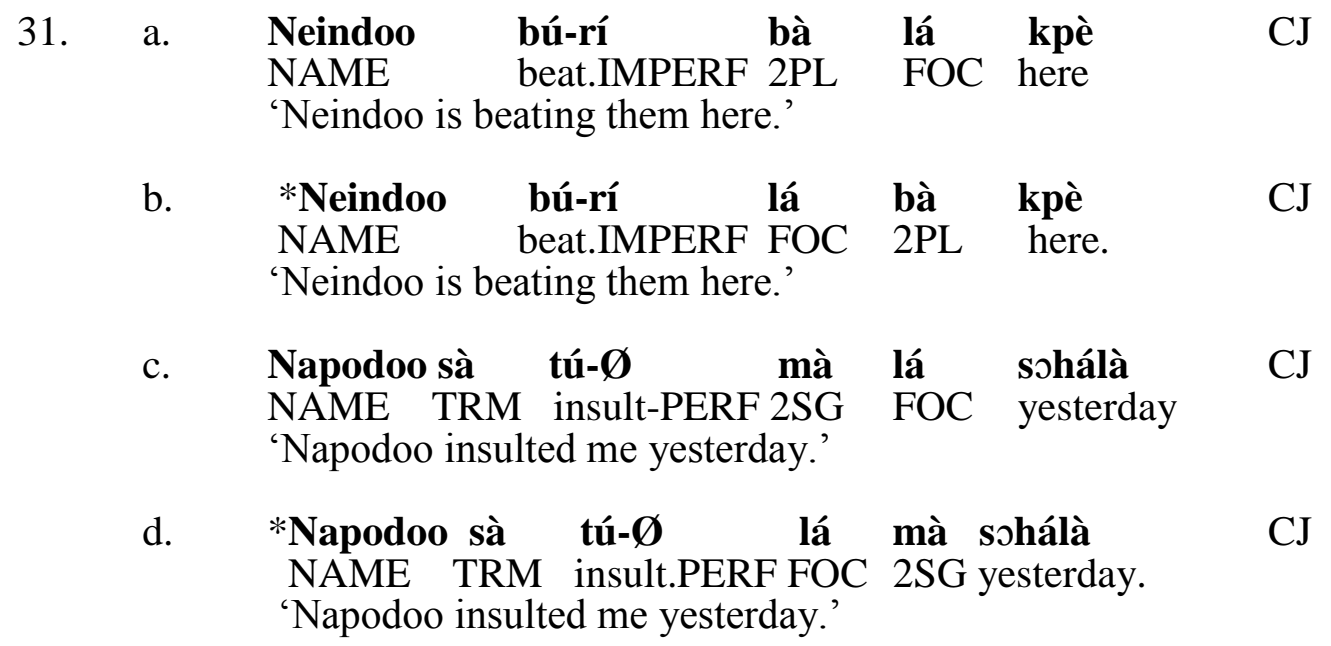

Issah (2013) argues that the syntactic variation of pronouns and the post verb la could be accounted for by either assuming that: (i) object pronouns are syntactically bound, or perhaps morphologically, as though in some sense they are suffixes in which case the object pronouns are clitics to the verb and (ii) that the weak pronominals always shift to the left of the la particle. This syntactic behaviour of weak pronouns when they co-occur with post verb particles has been established as a 
phenomenon in another (related) Gur language, Dagaare (Hiraiwa and Bodomo 2008: 249-250), which has a phonologically similar post-verb la. In Table 3 we summarize the descriptive observations so far made on the CJ/DJ forms in Dagbani.

This verbal paradigm and its interaction with the post verb particles as discussed in section 4 is very relevant in regard to Oti-Volta typology. For instance, other (genetically) related Gur languages such as Gurene (Atintono 2004; Dakubu 2007, 2000) and Kusaal (Issah 2006) also have the post verb particles which interact with aspectual markers. Guren $\varepsilon$ has the particle $\mathbf{m} \varepsilon$ which follows an imperfective form of the verb in the absence of an object, and also la which occurs when something must necessarily follow but not in the negative (like ya). Atintono (2004:132) asserts that:

the affirmative $\mathbf{m} \boldsymbol{\varepsilon}$ is also used after an imperfective verb if no object or adverb follows to indicate that the event is internally viewed as continuing.

On the distribution of the post verb la, Dakubu (2000: 61) argues that:

it never occurs with an intransitive verb or a verb whose Complement (which may be an NP, a pronoun, a locative NP or an entire clause is not expressed. 


\section{Table 3: Summary of the syntactic requirements of the Dagbani verbal paradigm}

Table 3: Summary of the syntactic requirements of the Dagbani verbal paradigm
\begin{tabular}{|l|l|l|l|l|l|}
\hline $\begin{array}{l}\text { verb } \\
\text { alternati } \\
\text { on }\end{array}$ & suffix & $\begin{array}{l}\text { use in } \\
\text { negative } \\
\text { clauses }\end{array}$ & syntactic requirements & $\begin{array}{l}\text { used with } \\
\text { post verb } \\
\text { particles }\end{array}$ & occurrence in relative clause \\
\hline $\begin{array}{l}\text { CJ } \\
\text { PERF }\end{array}$ & $-\varnothing$ & $\begin{array}{l}\text { occurs with } \\
\text { negative } \\
\text { clauses }\end{array}$ & $\begin{array}{l}\text { requires obligatory NP } \\
\text { object } \\
\text { can take an adjunct }\end{array}$ & $\begin{array}{l}\text { compatible } \\
\text { mi and la }\end{array}$ & occurs in relative clauses \\
\hline $\begin{array}{l}\text { DJ } \\
\text { PERF }\end{array}$ & - ya & $\begin{array}{l}\text { incompatible } \\
\text { with negative } \\
\text { sentences }\end{array}$ & $\begin{array}{l}\text { cannot co-occur NP } \\
\text { object } \\
\text { is compatible with } \\
\text { adjuncts }\end{array}$ & $\begin{array}{l}\text { incompatible } \\
\text { with mi and } \\
\text { la }\end{array}$ & $\begin{array}{l}\text { does not occur in relative } \\
\text { clauses }\end{array}$ \\
\hline $\begin{array}{l}\text { CJ } \\
\text { IMPER }\end{array}$ & -ri/di/ti & $\begin{array}{l}\text { compatible } \\
\text { with negative } \\
\text { clauses }\end{array}$ & $\begin{array}{l}\text { needs an obligatory NP } \\
\text { object } \\
\text { is compatible with } \\
\text { adjuncts }\end{array}$ & $\begin{array}{l}\text { compatible } \\
\text { with mi and } \\
\text { la }\end{array}$ & occurs in relative clauses \\
\hline $\begin{array}{l}\text { DJ } \\
\text { IMPERF }\end{array}$ & -ra/da/ta & $\begin{array}{l}\text { compatible } \\
\text { with negative } \\
\text { clauses }\end{array}$ & $\begin{array}{l}\text { cannot co-occur with NP } \\
\text { object } \\
\text { is incompatible with } \\
\text { adjuncts }\end{array}$ & $\begin{array}{l}\text { incompatible } \\
\text { with mi and } \\
\text { la }\end{array}$ & $\begin{array}{l}\text { - does not occur in relative } \\
\text { clauses. }\end{array}$ \\
\hline
\end{tabular}


Atintono (2004: 132) simply asserts that 'the yá modifier occurs after the verb to mark the completion of the event. It affirms a verb that is perfective'. However, there is a slight difference in terms of how Gurune and Dagbani treat their (-) ya marker. For instance, Dagbani orthography has always treated the perfective marker -ya as a suffix, while Gurenc treats the ya as a post verb particle, rather than a suffix, because according to Dakubu (2007), it gets stress like the initial root syllable of a lexeme. The data below taken from Atintono (2004: 133) illustrate the distribution of the Gurune post verb ya.

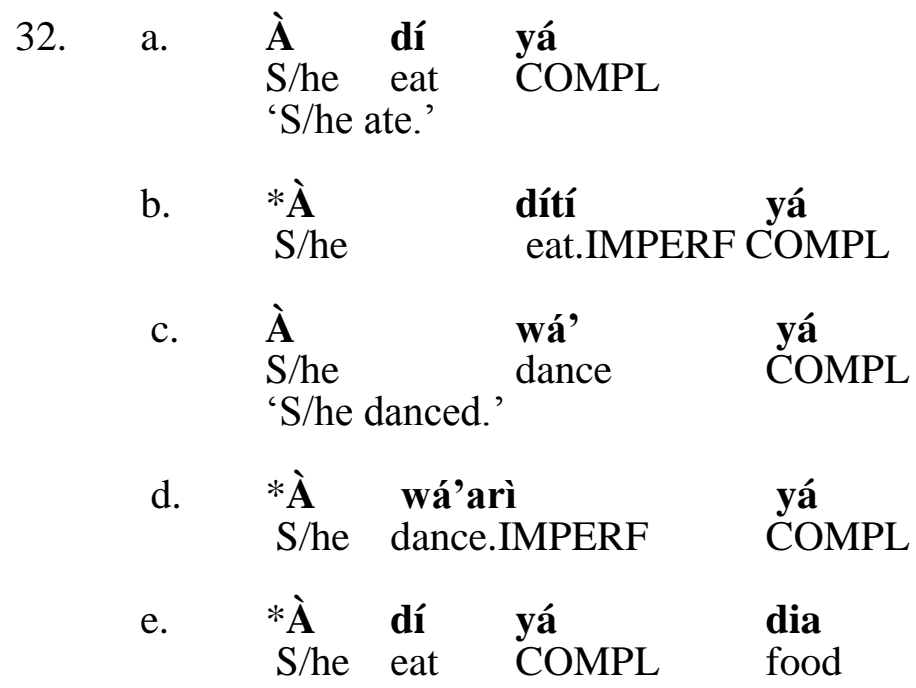

Descriptively therefore, the Gurun $\varepsilon$ post verb ya occurs clause finally just like its phonologically similar counterpart in Dagbani. It also does not occur with the imperfective aspect as evidenced in the ungrammatical sentences in (32b) and (32d). The distribution of the Gurun $\varepsilon$ post verb particles la and $\mathbf{m} \varepsilon$ is illustrated below with data taken from Atintono (2004: 73).
33. a. Poka la wa'ari me woman DEF dance.PROG AFF 'The woman is dancing.'
b. Pugela la dugeri la dia girl DEF cook. PROG FOC food 'The girl is cooking food.'




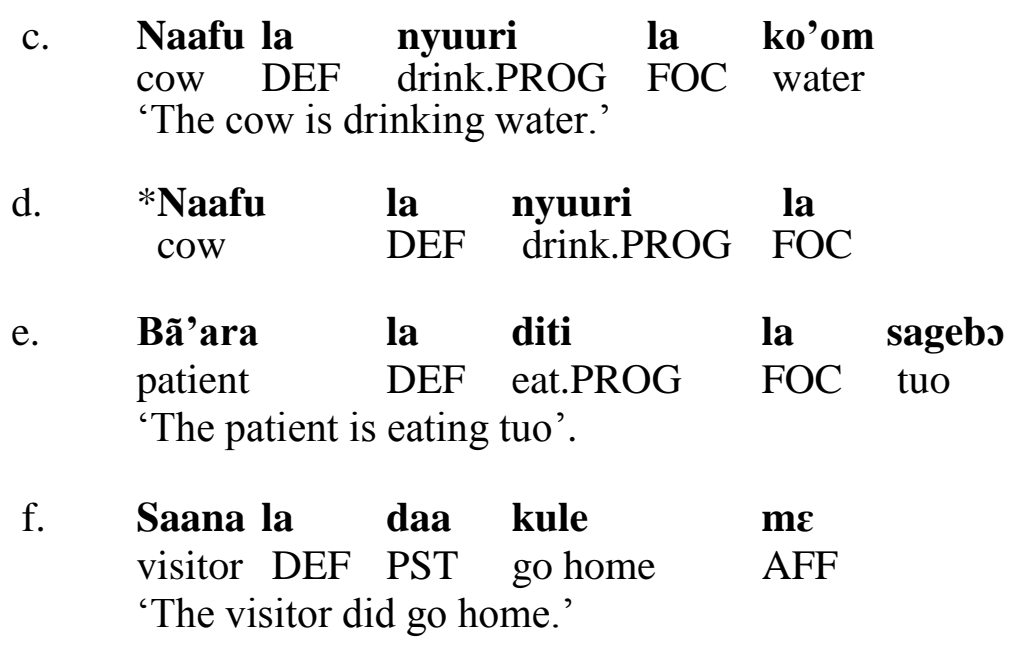

In Kusaal, a Gur language spoken in the Upper East region of Ghana, a similar paradigm exists, in the sense that Kusaal has the post verb particle ne, which follows the perfective form of the verb when something must follow, that is, the verb does not occur clause finally, (except for object pronouns) but never the conjoint imperfective form. In Kusaal too, the different morphological alternations call for different syntactic forms. It must however be pointed out that since the Agole Kusaal which I studied does not have the word-final vowels of the other languages, a distinction between -ri and -ra does not work for this language. The perfective form of the verb that is morphologically marked with $-\varnothing$ is almost always followed by post verb particle n\&, an NP object or an adjunct (except the object is a pronoun object, when the pronoun will precede the post verbal $\mathbf{n \varepsilon}$ ) while the form that is marked morphologically with -ya needs neither an NP object nor an adjunct and so occurs only clause finally in the canonical sentence. The former is what is termed as perfective 'conjoint', while the latter is referred to as perfective 'disjoint'. This explains why the ungrammaticality of sentence (34b) where the aspectual suffix -ya is assigned an NP object diib 'food'. Also, in (34d) the post verb ne occurs clause finally where in principle, it requires an NP object. The ungrammatical sentence in (34e) is also borne out of the fact that -ya occurs with an adjunct sumna 'well'. Abubakari (2011) discusses similar observations.

$\begin{array}{llll}\text { 34. } & \text { a. } & \begin{array}{l}\text { Ndego } \\ \text { Ndego }\end{array} & \text { dōg-yá } \\ \text { cook.PERF } & \text { DJ }\end{array}$ 


\begin{tabular}{|c|c|c|c|c|c|}
\hline b. & $\begin{array}{l}\text { *Ndego } \\
\text { Ndego } \\
\text { 'Ndego }\end{array}$ & $\begin{array}{c}\text { dōg-yá } \\
\text { cook.PERF } \\
\text { has cooked food.' }\end{array}$ & $\begin{array}{l}\text { dīib } \\
\text { food }\end{array}$ & & DJ \\
\hline c. & $\begin{array}{l}\text { Ndego } \\
\text { Ndego } \\
\text { 'Ndego }\end{array}$ & $\begin{array}{c}\text { dōg.Ø } \\
\text { cook.PERF } \\
\text { has cooked food.' }\end{array}$ & $\begin{array}{l}\mathbf{n} \bar{\varepsilon} \\
\text { PVP }\end{array}$ & $\begin{array}{l}\text { dīib } \\
\text { food }\end{array}$ & CJ \\
\hline d. & $\begin{array}{l}\text { *Ndego } \\
\text { Ndego } \\
\text { 'Ndego }\end{array}$ & $\begin{array}{c}\text { dīg. } \emptyset \\
\text { cook.PERF } \\
\text { has cooked food.' }\end{array}$ & $\begin{array}{l}\text { nE } \\
\text { PVP }\end{array}$ & & CJ \\
\hline e. & $\begin{array}{l}\text { *Bíig } \\
\text { Child } \\
\text { 'The ch }\end{array}$ & $\begin{array}{c}\text { lá } \\
\text { DEF cōg- } \\
\text { hild has cooked wel }\end{array}$ & ERF & $\begin{array}{l}\text { sūyjāā } \\
\text { well }\end{array}$ & CJ \\
\hline
\end{tabular}

The distribution of the perfective aspectual marker -ya and $\mathbf{n} \boldsymbol{\varepsilon}$ in Kusaal is not different from what has been observed of (-)ya and la in Dagbani and Gurune. This suggests that the syntactic requirement of these items could be described as being pervasive in Gur languages.

Just as we earlier observed of the post verb particles la in Dagbani and Gurune, pronouns differ in their syntactic relations with the post verb particle ne within the sentence structure of Kusaal. When pronouns occur with the post verb ne, they precede the particle, unlike full noun phrases (NPs) which follow it. For instance, in sentences (35a) and (35e) the object pronouns o 'him/her' and fu 'you' precede the post verb particle ne. Sentences (35b) (35d) are ungrammatical because they have pronoun objects which follow ne rather than preceding them. This is illustrated in (35).

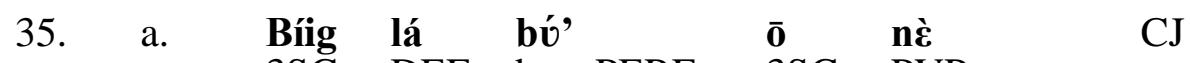

3SG DEF beat.PERF 3SG PVP

'The child has beaten him/her.'

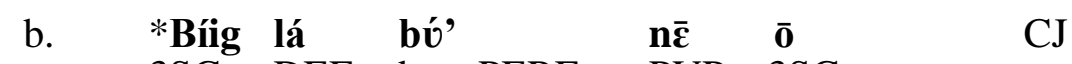

3SG DEF beat.PERF PVP $3 \mathrm{SG}$

'The child has beaten him/her.'

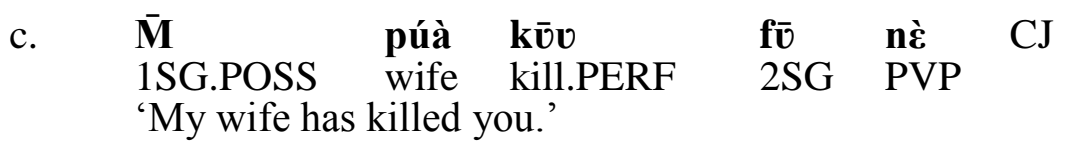


$\begin{array}{llllll}\text { d. } \quad * \overline{\mathbf{M}} & \text { púà } & \mathbf{k} \overline{\mathbf{v}} \mathbf{v} & \mathbf{n} \overline{\boldsymbol{\varepsilon}} & \mathbf{f} \overline{\mathbf{v}} . & \mathrm{CJ} \\ & \text { 1SG.POSS } & \begin{array}{l}\text { wife } \\ \text { kill.PERF }\end{array} & \text { PVP } & \text { 2SG } & \\ & \text { 'My wife has killed you.' }\end{array}$

Similar conclusions were drawn for the different syntactic relations that exist between pronouns and the post verb particle la in Dagbani and Guruns. According to Naden (2005: 3) Mampruli, also a Gur language, also has the suffix -ya which "marks perfective very much in the sense of the English Perfect - past with present relevance." The Mampruli data in (36) are taken from Naden (2005: 3) to illustrate the phenomenon in Mampruli.

36. a. U kyanni Tammali. "He went to Tamale (but may be back now)."

b. U kyayniya. " "He has gone (and is still away)."

c. *U kyanniya Tammali. "He has gone to Tamale."

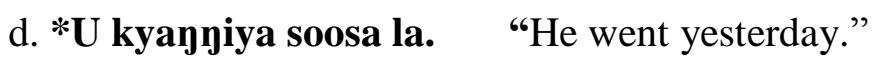

e. U dugi sinkaafa. "She cooked rice."

f. *U dugi. " "She cooked."

We could say based on the data in (36) that in Mampruli, just as observed of Dagbani, Kusaal and Gurune, the perfective marker -ya occurs clause finally. From the comparative perspective, one would be right to conclude that the different realization of the perfective and imperfective aspect is not only unique to Dagbani, but also other genetically related languages. It was also observed that the presence or absence of post verb particles in Dagbani and other Gur languages such as Mampruli, Dagaare, Kusaal and Gurune does interact with the aspect system of the languages. The distribution of the post verbal la in Mampruli is also demonstrated in (37).

37.
a.
$\begin{array}{lll}\text { U dugri } & \text { la } \\ \text { She cooking } & \text { FOC }\end{array}$
'She is/was cooking rice.'
b. $* \mathbf{U}$ dugri la.
She cooking FOC
'She is/was cooking.'

sinkaafa.

\section{Summary and Conclusions}

This paper set forth to discuss the verbal morphology of Dagbani with special attention on the correlation between verbal morphology and sentence structure. 
Focusing on verbal inflection, the discussion centred on the relation between inflections and complement placement. It is established that the CJ/DJ verb form encodes differences in morphology, syntax and information structure. The CJ form of the verb obligatorily needs some element (NP object, adjunct) to follow it whereas the disjoint form can (but does not need to) be in sentence final position. The interaction between negation and the verbal alternation is also investigated. It was established that there is a co-occurrence relation between the perfective DJ form and negation as well as focus marking and the verbal paradigm.

In an attempt to account for the distribution of the conjoint and disjoint verb forms in Dagbani, three proposals were considered: the incorporated pronoun hypothesis, the medio-passive morpheme hypothesis and the focus hypothesis. I concluded based on empirical evidence that the CJ/DJ correlated with focus suggesting that the focus hypothesis best accounts for the CJ/DJ forms in Dagbani as has been established in other Gur and non-Gur languages.

A comparative flavour was injected into the work by looking at the verbal alternation and its interaction with the sentence structure in regard to Oti-Volta typology. Drawing on data from genetically related languages such as: Gurune, Kusaal, Mampruli and Dagaare, it is established that the interaction seen between the post-verb particles and the verbal paradigm of Dagbani appears to be a typological phenomenon which can be observed in several other Gur languages in the Oti-Volta subfamily. The paper therefore, contributes to the literature on verb morphology by bringing data from a lesser known language and related ones. This could consequently contribute to our knowledge of not only the verb morphology on Dagbani, but also, a cross linguistic contribution to the understanding of the verbal alternation and its correlation with sentence patterns in natural languages.

\section{References}

Abubakari, H., 2011. Object sharing as symmetric sharing: predicate clefting and Serial Verb Constructions in Kusaal. M.Phil Thesis, University of Troms $\varnothing$, Norway.

Adger, D., 2004. Core syntax- A minimalist approach; Oxford: Oxford University Press.

Atintono. A.S., 2005. Aspectual modifiers in Gurune. In M. E. Kropp Dakubu and E. K. Osam, eds., Studies in Languages of the Volta Basin (Proceedings of the Annual Colloquium of the Legon Trondheim Linguistics Project) Vol 3: 33-42.

Atintono. A. S., 2004. A morpho-syntactic study of the Gurune verb. M.Phil Thesis, Department of Linguistics, University of Ghana, Legon. 
Buell, L., 2005. Issues in Zulu morphosyntax. Ph. D. Dissertation, University of California, Los Angeles.

Buell, L., 2006. The Zulu conjoint/disjoint verb alternation: focus or constituency? ZAS Papers in Linguistics 43: 9-30.

Buell, L. and K. Riedel, 2008. The conjoint/disjoint alternation in Sambaa. Paper presented at Bantu Syntax Project, Leiden University.

Cahill, M., 1999. Aspects of the Phonology and Morphology of Konni. PhD Dissertation, Ohio State University.

Comrie, B., 1976. Aspect, An introduction to the study of verbal aspect and related problems. Cambridge: Cambridge University Press.

Creissels, D., 1996. Conjoint and disjoint verb forms in Setswana. South African Journal of African Languages 16: 109-115.

Dakubu, M. E. Kropp, 2007. Tone and the Gurene verb. Studies in the Languages of the Volta Basin 4.2: 52-62.

Dakubu, M. E. Kropp, 2006. Prosodic features of the Gurene verb. Gur Papers/ Cahiers Voltaïques 7: 16-27.

Dakubu, M. E. Kropp, 2000. The particle la in Gurene. Gur Papers/Cahiers Voltaiques 5: 59-65.

Dakubu, M. E. Kropp, 1995. A Grammar of Gurune: Trial edition, Legon: Language Centre, University of Ghana.

Dakubu, M. E. Kropp, 1989. The Dagaare verbal word and phrase. Ms. Language Centre, University of Ghana.

Dryer, M. S., 2005. Position of tense-aspect affixes. In Martin Haspelmath, Matthew S. Dryer, David Gil and Bernard Comrie, eds., The World Atlas of Language Structures. Oxford: Oxford University Press.

Givon, T., 1975. Focus and the scope of assertion: some Bantu evidence. Studies in African Linguistics 6.2: 185-205.

Güldemann, T., 2003. Present progressive vis-à-vis predication focus in Bantu: a verbal category between semantics and pragmatics. Studies in Language 27: 323-360.

Hiraiwa, Ken and Adams Bodomo, 2008. Object-sharing as symmetric sharing: evidence from Dàgáárè. In Charles B. Chang and Hannah J. Haynie, eds., Proceedings of the 26th West Coast Conference on Formal Linguistics, pp. 243-251. Somerville, MA: Cascadilla Proceedings Project.

Hudu, F., 2012. Focus particles in Dagbani - a descriptive analysis. Journal of West African Languages 39.1: 97-107.

Hudu, F., 2006. Focus marking in Dagbani. Paper presented at the 23rd Northwest Linguistics Conference, Victoria BC, Feb. 17-19. 
Issah, A. S., 2013a. The structure of the Dagbani simple noun phrase. South African Journal of African Languages 33.2: 203-212.

Issah, A. S., 2013b. The function of the post verb la in Dagbani. Studies in African Linguistics 42.2: 153-174.

Issah, A. S., 2012. Phrasal identification and contrastive focus in Dagbani”. Journal of West African Languages 39.1: 75-96.

Issah, A. S., 2008. Information Packaging in Dagbani, M.Phil Thesis, University of Troms $\varnothing$, Norway.

Issah A. S., 2006. A survey of the Kusaal noun phrase. ms. Ghana Institute of Linguistics, Literacy and Bible Translation, Tamale.

Manessy, G., 1963. Les particules affirmatives postverbales dans le groupe voltaïque. Bulletin de l'IFAN t. xxv, sér.B. no 1-2: 109-124.

Naden, T., 2005. Sentence perspective in Mampruli. Ms. GILLBT, Tamale.

Naden, T., 1989. The Gur Languages. In John Bendor-Samuel, ed., The Niger-Congo Languages. Lanham NY and London: University Pressof America.

Naden, A. J., 1988. Language, history and legend in Northern Ghana, Ms. GILLBT, Tamale.

Nicole, J., 1999. Noun classes in the Gur languages. ms. Transl. Alison Winton from Jacques Nicole, 1999. Les classes nominales dans les langues voltaiques. Esquisse d'un cadre de description. Lome, Togo: SIL.

Nurse, Derek, 2006. Focus in Bantu: verbal morphology and function. ZAS Papers in Linguistics 43: 189-207.

Olawsky, K. J., 1999. Aspects of Dagbani Grammar with Special Emphasis on Phonology and Morphology. PhD Dissertation, Munich.

Osam, E. K., 2003. An introduction to the verbal and multi-verbal system of Akan. In Dorothee Beermann and Lars Hellan, eds., Proceedings of the Workshop on MultiVerb Constructions. Trondheim.

Reineke, Brigitte and Gudrun Miehe, 2005. Diathesis alternation in some Gur languages. In Erhard F. K. Voeltz, ed., Studies in African Linguistic Typology, pp. 337-360. Typological Studies in Language Vol. 64. Amsterdam/Philadelphia: John Benjamins Publishing Company.

Saanchi, J. A., 2003. Aspect and the Dagaare verb. Cahiers Voltaiques/Gur Papers 6: 101106.

Salifu, A. T., 2012. Yeltoyatayimalisi. Unpublished creative writing project work submitted to the Department of Gur-Gonja, University of Education, Winneba.

Sharman, J. C., 1956. The tabulation of tenses in a Bantu language (Bemba: Northern Rhodesia). Africa 16: 29-46. 
Schwarz, A., 2008. A verb focus typology in Buli (Gur). A paper presented at the predicate focus workshop (University of Potsdam) November 14-15, 2008.

van der Wal, J., 2009. Word Order and Information Structure in Makhuwa-Enahara. PhD Thesis, University of Leiden.

van der Wal, Jenneke, 2013. What is the conjoint/disjoint alternation in Bantu languages? Ms. Cambridge University.

Voeltz, Erhard F. K., 2004. Long and short verb forms in Zulu. Paper presented at the Annual Conference on African Linguistics, Boston MA.

Yakubu A., 2012. Naanigoo. Unpublished creative writing project work submitted to the Department of Gur-Gonja, University of Education, Winneba. 